\title{
PENINGKATAN PENGETAHUAN TERKAIT VAKSINASI COVID-19 DI PANTI ASUHAN RAUDATUL AITAM BANDAR LAMPUNG
}

https://doi.org/10.33024/jkpm.v4i6.4922

$$
\text { Rika Yulendasari }{ }^{1}, \text { Rahayu }^{2 *}
$$

\section{Program Studi Ilmu Keperawatan Universitas Malahayati}

Disubmit: 26 Agustus 2021 Diterima: 28 Agustus $2021 \quad$ Diterbitkan: 01 Desember 2021

Email Korespondensi: ayurahayu1192@gmail.com

\begin{abstract}
ABSTRAK
Berawal dari munculnya kasus pneumonia di Wuhan, China yang belum diketahui penyebabnya. Kasus ini terjadi pada akhir tahun 2019, tepatnya pada bulan Desember. Menurut hasil epidemiologi, kasus pneumonia yang terjadi terkait dengan pasar ikan di wilayah Wuhan. WHO menetapkan penyakit ini diberi nama Coronavirus disease 2019 atau bisa juga disebut COVID-19. Tujuan setelah penyuluhan kesehatan adalah untuk menambah pengetahuan terkait vaksinasi COVID-19 dan partisipan penyuluhan dapat mengikuti program vaksinasi yang diselenggarakan oleh pemerintah. Ada juga kegiatan yang dicoba berupa penyuluhan kesehatan dengan menggunakan flip chart dan leaflet. Terjadi peningkatan pengetahuan hingga 80\% terkait vaksinasi COVID-19 pada partisipan penyuluhan di panti asuhan Raudatul Aitam.
\end{abstract}

Kata kunci: Pengetahuan; Vaksinasi; COVID-19; Panti Asuhan Anak

\begin{abstract}
Starting from the emergence of cases of pneumonia in Wuhan, China whose cause is not yet known. This case occurred at the end of 2019, precisely in December. According to epidemiological results, the pneumonia cases that occurred were related to a fish market in the Wuhan area. WHO has determined this disease to be named Coronavirus disease 2019 or it can also be called COVID19. The goal after health education is to increase knowledge regarding COVID19 vaccination and counseling participants can take part in vaccination programs organized by the government. There are also activities that are tried in the form of health education using flip charts and leaflets. There was an increase in knowledge of up to $80 \%$ related to COVID-19 vaccination among counseling participants at the Raudatul Aitam orphanage.
\end{abstract}

Keywords: Knowledge; Vaccinations; COVID-19; Children's Orphanage 


\section{PENDAHULUAN}

Berawal dari kemunculan kasus pneumonia di Wuhan,China yang penyebabnya belum diketahui . Kasus ini terjadi pada penghujung tahun 2019 tepatnya di bulan Desember. Menurut hasil epidemiologi, kasus pneumonia yang terjadi berkaitan dengan pasar ikan yang berada di daerah Wuhan (Febriyanti, Choliq, \& Mukti, 2021). WHO menetapkan bahwa penyakit ini diberi nama Coronavirus disease 2019 atau bisa juga disebut COVID-19. COVID-19 ialah penyakit menular yang bisa ditularkan antar manusia dan hewan. Gejala coronavirus disease 19 umumnya menyerang pernapasan akut yang mengakibatkan penderita menjadi sesak nafas, batuk, dan demam. COVID-19 juga bisa menyebabkan penderita mengalami pneumonia, komplikasi lainnya bisa mengakibatkan kerusakan pada ginjal dan dapat menyebabkan kematianpada kasus yang parah (Syakurah \& Moudy, 2020 ; Iswandi \& Roro, 2020 ; Basuki, Faizah, Pitaloka, \& Suhartono, 2021).

kasus COVID-19 semakin melonjak setelah kemunculan kasus di Wuhan, China. Di China kasus terkonfirmasi pada tanggal 30 Januari 2020 mencapai 7.736 ribu jiwa dan 86 kasus dari berbagai negara (Sari \& Rombot, 2021). WHO mengatakan COVID-19 merupakan pandemi pada tanggal 12 Maret 2020. jumlah kasus terkonfirmasi pada tanggal 23 April 2020 mencapai angka 2.549.632 ribu jiwa dan angka kematian secara global menyentuh 175.825 ribu jiwa (Putri \& Rahmah, 2020; Hasanuddin, Fadli, Sulaeman, Purnama, \& Sastria, 2021).

Pada tanggal 02 Maret 2020 terdapat 2 kasus awal terkonfirmasi di Indonesia. Penambahan jumlah kasus di Indonesia melonjak, terdapat 10.551 kasus terkonfirmasi dan 800 orang yang meninggal. Angka kasus di Indonesia semakin hari semakin meningkat dibuktikan dengan data kasus terkonfirmasi pada tanggal 16 Juni 2020 menyentuh angka 40.400 kasus dan 2.231 orang yang meninggal (Purnamasari \& Raharyani, 2020). Vaksin merupakan solusi yang tepat untuk memutus rantai penyebaran penyakit yang disebabkan oleh corona virus disease 2019. Pemberian vaksin secara gratis dilakukan oleh pemerintah sejalan dengan Peraturan Menteri Kesehatan RI No 10 Tahun 2021 mengenai Pelsaksanaan Vaksinasi dalam Rangka Penanggulangan Pandemi COVID 19 untuk semua masyarakat (Arumsari, Desty, \& Kusumo, 2021).

Pada 19-30 September 2020 Dapartemen Kesehatan bersama sebagian organisasi (AGI, UNICEF dan WHO) melakukan survei daring guna mengenali penerimaan masyarakat umum atas vaksin COVID-19. Tercatat melibatkan lebih dari 115.000 responsden yang berasal dari 34 provinsi di Indonesia. Dari hasil survei dikenal kalau 658 responden bersedia menerima vaksin COVID19 bila disediakan Pemerintah, sebaliknya 8 persen di antara lain menolak. 274 sisanya mempunyai keraguan terhadap rencana Pemerintah buat mendistribusikan vaksin COVID-19. Bersumber padainformasi responden yang dilakukan Dapartemen Kesehatan bersama Indonesian Technical Advisory Group on Immunization (ITAGI) yang dirilis pada Oktober 2020, membuktikan bahwa masih terdapat sekitar 7,6 \% warga yang menolak buat divaksinasi dan $26,6 \%$ masyarakat masih bingung dan belum memberikan keputusan ( Sigalingging \& Santoso, 2021).

Dari berbagai sebab tersebut sehingga kami tertarik melaksanakan riset pendek dengan judul Peningkatan Pengetahuan Terkait Vaksinasi COVID-19 guna mendorong keberhasilan program vaksinasi. 


\section{MASALAH}

Alasan kami memilih panti asuhan sebagai tempat penelitian karena anak-anak yang tinggal di panti asuhan sebagian besar belum melakukan vaksinasi COVID19. Selai itu, pengetahuan tentang vaksinasi COVID-19 masih sangat minim di lingkungan anak-anak yang tingal di Panti Asuhan Raudatul Aitam. Berdasarkan masalah diatas, maka perlu dilakukan penelitian tentang peningkatan pengetahuan terhadap vaksinasi COVID-19 guna mendorong keberhasilan program vaksinasi.

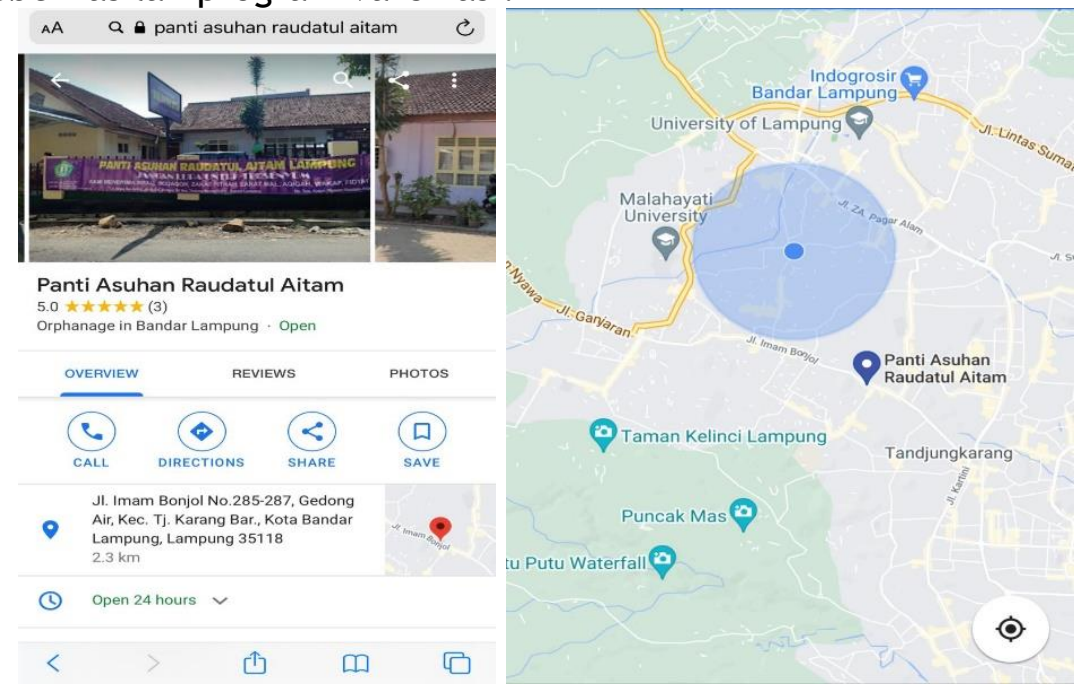

Gambar 2.1 Peta Lokasi Pengabdian Kepada Masyarakat

\section{METODE}

a. Tujuan Persiapan

Tahap pertama dari kegiatan ini adalah pre planning, mempersiapkan leaflet dan LCD proyektor. Termpat dan alat lainnya disiapkan oleh pengurus panti". Pembuatan leaflet dimulai pada tanggal 20 Agustus 2021, dilakukan pemeriksaan untuk persiapan penyuluhan.

b. Tahap Pelaksanaan

Tahap pelaksanaan acara ini dengan memberitahukan kepada pengurus panti asuhan Raudatul Aitam untuk dapat mengarahkan anak-anak panti asuhan agar berkumpul dan dilanjutkan dengan penyuluhan kesehatan peningkatan pengetahuan terkait vaksinasi COVID-19.

c. Evaluasi

i. Struktur

Peserta yang hadir berjumlah 20 orang anak-anak panti asuhan Raudatul Aitam. Tempat sudah sesuai dengan rencana yang sudah dibuat dan perlengkapaan penunjang penyuluhan sudah dipersiapkan dengan baik dan sudah digunakan sesuai dengan perencanaan. Bahasa yang digunakan dalam penyampaian sudah komunikatif dan mudah dipahami , para peserta panti dapat memahami materi yang sudah disampaikan oleh tim pengabdian masyarakat dan dapat memudahkan audiens selama pelatihan dan diskusi sedang berlangsung

ii. Proses

Pelaksanaan kegiatan pukul 13.00-1400 WIB. Sesuai dengan jadwal yang telah direncanakan 


\section{HASIL DAN PEMBAHASAN}

Metode pelaksanaan dalam kegiatan penyuluhan kesehatan tentang vaksinasi ini dilakukan pada tanggal 25 Agustus 2021 di panti asuhan Raudatul Aitam Gedung Air Bandar Lampung. Sasaran dari pelaksanaan penyuluhan singkat ini adalah anak-anak panti asuhan Raudatul Aitam yang belum mengikuti program vaksinasi COVID-19 dan belum paham tentang vaksinasi COVID-19. Media serta alat yang dipakai dalam penyuluhan kesehatan ini adalah leaflet dan LCD proyektor. Dalam penyuluhan kesehatan ini kami menggunakan metode ceramah, tanya jawab dan evaluasi dengan menanyakan kembali materi yang telah disampaikan. Hasil dari evaluasi menunjukkan lebih dari 80\% partisipan penyuluhan yang ada di panti asuhan Raudatul Aitam mampu menjawab pertanyaan yang diberikan oleh penyuluh dengan baik.

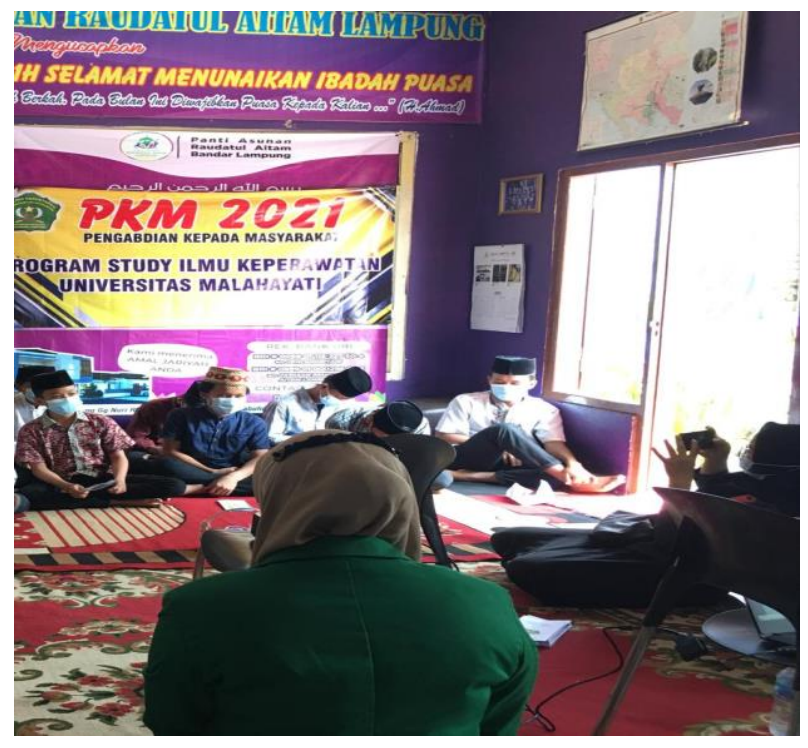

Gambar 4.1 Kegiatan PKM

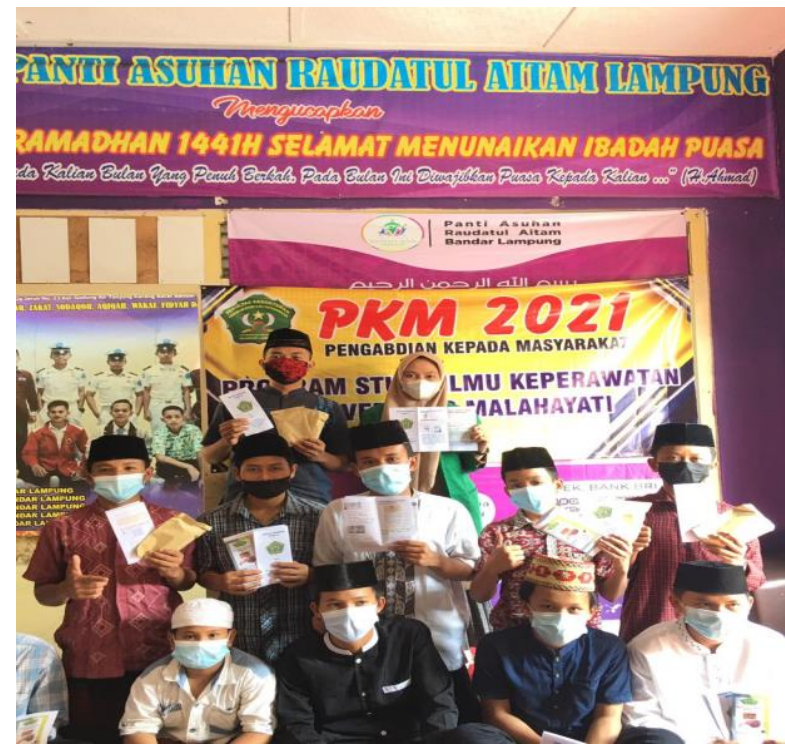

Gambar 4.2 Kegiatan PKM 


\section{KESIMPULAN}

Vaksinasi merupakan keadaan di dalam badan, dimana seorang menjadi kebal dan terlindungi dari penyakit tertentu sehingga disaat terkena penyakit tersebut maka hanya akan mengalami gejala ringan dari penyakit tersebut. Oleh karena itu vaksinasi sangat penting dilakukan guna mengurangi angka kesakitan dan angka kematian akibat virus COVID-19. Penyuluhan kesehatan ini diharapkan dapat meningkatkan pengetahuan terkait vaksinasi COVID-19 di panti asuhan Raudatul Aitam Gedung Air Bandar Lampung sehingga peserta dapat memahami dan mengerti akan pentingnya vaksinasi sehingga peserta dapat ikut serta dalam program vaksinasi yang diselenggarakan oleh pemerintah.

\section{DAFTAR PUSTAKA}

Arumsari, W., Desty, R. T., \& Kusumo, W. E. G. (2021). Gambaran Penerimaan Vaksin COVID-19 di Kota Semarang. Indonesian Journal of sHealth Community, 2(1).

Basuki, H. O., Faizah, H. N., Pitaloka, D., \& Suhartono, S. (2021). Pendidikan Kesehatan Tentang Rumah Sehat Covid-19 Bagi Kader Covid-19 Di Desa Bogorejo Merakurak Tuban Tahun 2021. Abdimasnu: Jurnal Pengabdian kepada Masyarakat, 1(1).

Febriyanti, N., Choliq, M. I., \& Mukti, A. W. (2021). Hubungan Tingkat Pengetahuan dan Kesediaan Vaksinasi Covid-19 pada Warga Kelurahan Dukuh Menanggal Kota Surabaya. SNHRP, 3, 36-42.

Hasanuddin, I., Fadli, F., Sulaeman, S., Purnama, J., \& Sastria, A. (2021). Donasi Masker Untuk Kesehatan Masyarakat Dalam Pencegahan Penularan Covid-19

Iswandi, D., \& Roro, R. W. (2020). Peningkatan Pengetahuan Tenaga Kesehatan Mengenai Penyakit Corona Virus Disease (COVID) 19 pada Pasien Dewasa. Jurnal Pengabdian Masyarakat Ruwa Jurai.

Purnamasari, I., \& Raharyani, A. E. (2020). Tingkat pengetahuan dan perilaku masyarakat Kabupaten Wonosobo tentang Covid-19. Jurnal Ilmiah Kesehatan, 10(1), 33-42.

Putri, N. W., \& Rahmah, S. P. (2020). Edukasi Kesehatan untuk Isolasi Mandiri dalam Upaya Penanganan COVID-19 di Kanagarian Koto Baru, Kabupaten Solok. Jurnal Abdidas, 1(6), 547-553.

Sari, W., Siagian, I. E., \& Rombot, D. V. (2021). Gambaran penyebaran COVID-19 di Provinsi Sulawesi Selatan pada bulan Maret-Juli 2020. JURNAL KEDOKTERAN KOMUNITAS DAN TROPIK, 8(02).

Sigalingging, Y. E., \& Santoso, A. P. A. (2021). Analisis Yuridis Pengaturan Sanksi Bagi Penolak Vaksinasi Covid-19. JISIP (Jurnal Ilmu Sosial dan Pendidikan), 5(3).

Syakurah, R. A., \& Moudy, J. (2020). Pengetahuan terkait usaha pencegahan Coronavirus Disease (COVID-19) di Indonesia. HIGEIA (Journal of Public Health Research and Development), 4(3), 333-346. 